\title{
Acute glycemic control in diabetics. How sweet is optimal? Con: Just as sweet as in nondiabetic is better
}

\author{
Moritoki Egi(D)
}

\begin{abstract}
This review is for Con side of "Pro-Con debate" on the optimal target of blood glucose levels in patients with chronic hyperglycemia (e.g. premorbid HbA1c level > 7\%). Currently, international guideline recommended that blood glucose level $\leq 180 \mathrm{mg} / \mathrm{dL}$ in critically ill patients irrespective of presence or absence of premorbid diabetes. However, there are several studies to generate the hypothesis that liberal glycemic control (e.g., target blood glucose level 180-250 mg/dL) may be beneficial in critically ill patients with premorbid hyperglycemia. Although there is before-after study to report its safety and feasibility, it should be noted that this strategy may have a potential to increase the risk of infection, glycosuria, and polyneuropathy. Furthermore, there is randomized controlled study which showed the potential harm of liberal glycemic control in patients with premorbid hyperglycemia. Additionally, there are lots of uncertainty about the candidate and methodology of such a permissive hyperglycemia. With considering these facts, it might be better to keep target of blood glucose level in patients with diabetes the same as patients without diabetes ( $\leq 180 \mathrm{mg} / \mathrm{dL})$, until randomized control study as like LUCID (the Liberal GIUcose Control in Critically III Patients with Pre-existing Type 2 Diabetes) trial will justify its risk and benefit.
\end{abstract}

Keywords: Diabetes, Chronic, Hyperglycemia, Liberal

\section{Background}

This review is one of "Pro-Con" reviews to discuss the optimal target of blood glucose levels in patients with chronic hyperglycemia (e.g., premorbid HbA1c level > 7\%). It is for the "Con" side standing for the statement that optimal target of acute glycemic control in patients with chronic hyperglycemia was same as in non-diabetic patients $(\leq 180 \mathrm{mg} / \mathrm{dL})$.

Although intensive insulin therapy (target blood glucose $80-110 \mathrm{mg} / \mathrm{dL}$ ) had been reported to lower the mortality in a single-center randomized controlled trial [1], cumulative evidences show that such a glycemic management had significantly higher incidence of hypoglycemia and no further merit on the mortality and morbidity. According to the results of NICE-SUGAR trial [2] and subsequent meta-analysis [3], international guideline for management

Correspondence: moriori@tg8.so-net.ne.jp

Please click here to read 'Pro' article on this topic.

Department of Anesthesiology, Kobe University Hospital, 7 -5-1

Kusunoki-cho, Chuo-ku, Kobe City 650-0017, Japan of sepsis recommended to maintain blood glucose level $\leq$ $180 \mathrm{mg} / \mathrm{dL}$ in acute illness [4, 5].

\section{How differently the target of blood glucose level is recommended in patients with and without diabetes}

NICE-SUGAR trial had reported that intensive glucose control increased mortality among adults in the ICU. In other words, a blood glucose target of $\leq 180 \mathrm{mg} / \mathrm{dL}$ resulted in lower mortality than did a target of 81 to $108 \mathrm{mg} / \mathrm{dL}$ [2]. This effect was not significantly different between patients with and without diabetes $(p=0.60)$. Recently, one study reported estimation of optimal blood glucose level in critically ill patients using network meta-analysis [6]. However, this study could not analyze the optimal target in acute ill patients with premorbid diabetes due to the limit of evidence. Accordingly, current guideline recommends the same target of blood glucose level $(\leq 180 \mathrm{mg} / \mathrm{dL})$ irrespective of presence or absence of premorbid diabetes [5].

(c) The Author(s). 2018 Open Access This article is distributed under the terms of the Creative Commons Attribution 4.0 International License (http://creativecommons.org/licenses/by/4.0/), which permits unrestricted use, distribution, and 


\section{The liberal glycemic control in critically ill patients with chronic hyperglycemia}

There are studies shown that relationship between hyperglycemia and outcomes was altered by the presence of diabetes mellitus [7-12]. Furthermore, there are studies reported that premorbid hyperglycemia might interact the relationship between acute glycemic control and mortality [13-15]. Accordingly, these observational studies suggest that a liberal glycemic level (e.g., between 180 and $250 \mathrm{mg} / \mathrm{dL}$ ) in critically ill patients with chronic hyperglycemia may be beneficial [16-19].

However, there are limited controlled studies to justify the benefit or harm of such a liberal glycemic control in particular cohort. Recent before-after study conducted in critically ill patients with diabetes shows that liberal glucose control was associated with decrease in insulin administration without any difference on clinical outcomes. This study also showed that the incidence of hypoglycemia was decreased in patients with chronic hyperglycemia [20]. However, there are several concerns on such a "permissive hyperglycemia" in critically ill patients with diabetes.

\section{There are concerns of liberal glycemic control in patients with diabetes}

First concern on the "permissive hyperglycemia" in patients with diabetes is the risk of infection. Rayfield et al. had reported that there is significant association of mean glycemia and the risk of infection in diabetic patients [21]. There is a diminution in intracellular bactericidal activity of leukocytes and lower serum opsonic activity for bacteria in patients with poorly controlled diabetes. It should be noted that Centers for Disease Control and Prevention Guideline for the prevention of surgical site infection recommends to avoid the hyperglycemia as $200 \mathrm{mg} / \mathrm{dL}$ in patients with and without diabetes (category IA-strong recommendation; high to moderatequality evidence) [22].

Second concern is the risk of glycosuria. Ruhnau et al. conducted prospective study to assess the renal threshold for glucose in patients with non-insulin-dependent diabetes [23]. At the level of $180 \mathrm{mg} / \mathrm{dL}$ of blood glucose, about half of the patients had partial glycosuria and the rest had no glycosuria. However, at the level of $250 \mathrm{mg} / \mathrm{dL}$, approximately two thirds of the patients had persistent glycosuria. In critically ill patients, to maintain intravenous blood volume is relevant. Therefore, we might be able to prevent the glycosuria accompanied with permissive hyperglycemia.

Third concern is the risk of polyneuropathy. The polyneuropathy is common in patients with longer duration of diabetes and chronic hyperglycemia [24]. The analysis of pooled dataset of two randomized controlled trials shows that lowering blood glucose control had a non-significant trend to decrease the incidence of critical illness-induced polyneuropathy in patients with diabetes (43.9\% vs $32.6 \%$; odds ratio $=0.62, p=0.25)$ [25]. These findings may suggest that hyperglycemia might be better to be avoided to prevent polyneuropathy in critically ill patients with diabetes.

In different words, these three concerns might suggest that conventional control may be beneficial to lower the risk of infection, to avoid the derangement due to the glycosuria, and to prevent the polyneuropathy in comparison with the liberal glycemic control in acute ill patients with chronic hyperglycemia.

\section{The randomized controlled trial to assess "permissive hyperglycemia" in acute ill patients with hyperglycemia}

The DIGAMI study is a multicenter randomized controlled trial comparing between blood glucose level < $198 \mathrm{mg} / \mathrm{dL}$ and no use of insulin in post-myocardial infarction patients with HbA1c of around 8\% [26]. The blood glucose level $24 \mathrm{~h}$ after randomization in no insulin group was $211 \mathrm{mg} / \mathrm{dL}$ in average, which is significantly higher than those of $173 \mathrm{mg} / \mathrm{dL}$ in the group of < $198 \mathrm{mg} / \mathrm{dL}$. In the DIGAMI study, blood glucose control $<198 \mathrm{mg} / \mathrm{dL}$ significantly reduced 1 -year mortality in comparison with those without using insulin. As DIGAMI study was conducted 25 years ago, their finding may not be generalized into current practice. Nonetheless, we should note that there is interventional study to show that the permissive hyperglycemia may increase the mortality in comparison with current usual glycemic control in patients with premorbid hyperglycemia.

\section{Conclusion}

Liberal glycemic control is the concept of permissive acute hyperglycemia in critically ill patients with premorbid hyperglycemia. Although there are several studies to support this hypothesis and to report its safety and feasibility, we should note that this strategy may have a potential to increase the risk of infection, glycosuria, and polyneuropathy. Furthermore, there is randomized controlled study which showed the potential harm of liberal glycemic control in patients with premorbid hyperglycemia. Additionally, there are lots of uncertainty about the candidate and methodology of such a permissive hyperglycemia.

Considering above facts, it might be better to keep target of blood glucose level in patients with diabetes as same as in patients without diabetes $(\leq 180 \mathrm{mg} /$ $\mathrm{dL}$ ), until randomized control study as like LUCID (the Liberal GlUcose Control in Critically Ill Patients with Pre-existing Type 2 Diabetes) trial justify its risk and benefit. 


\section{Funding}

This work was supported by Grant-in-Aid for Scientific Research (16K10936).

\section{Authors' contributions}

ME conceptualized, drafted, critically revised, and approved the final manuscript.

\section{Ethics approval and consent to participate}

$\mathrm{Nil}$ as this is review article

\section{Consent for publication}

Nil as this is review article

\section{Competing interests}

The authors declare that they have no competing interests.

\section{Publisher's Note}

Springer Nature remains neutral with regard to jurisdictional claims in published maps and institutional affiliations.

Received: 2 September 2018 Accepted: 27 September 2018

Published online: 06 November 2018

\section{References}

1. van den Berghe G, Wouters P, Weekers F, Verwaest C, Bruyninckx F, Schetz M, et al. Intensive insulin therapy in critically ill patients. N Engl J Med. 2001; 345(19):1359-67.

2. Finfer S, Chittock DR, Su SY, Blair D, Foster D, Dhingra V, et al. Intensive versus conventional glucose control in critically ill patients. N Engl J Med. 2009;360(13):1283-97.

3. Friedrich JO, Chant C, Adhikari NK. Does intensive insulin therapy really reduce mortality in critically ill surgical patients? A reanalysis of metaanalytic data. Crit Care. 2010;14(5):324

4. Nolan JP, Soar J, Cariou A, Cronberg T, Moulaert VR, Deakin CD, et al. European resuscitation council and European society of intensive care medicine guidelines for post-resuscitation care 2015: Section 5 of the European Resuscitation Council Guidelines for Resuscitation 2015. Resuscitation. 2015:95:202-22.

5. Rhodes A, Evans LE, Alhazzani W, Levy MM, Antonelli M, Ferrer R, et al. Surviving sepsis campaign: international guidelines for management of sepsis and septic shock: 2016. Intensive Care Med. 2017:43(3):304-77.

6. Yatabe T, Inoue S, Sakaguchi M, Egi M. The optimal target for acute glycemic control in critically ill patients: a network meta-analysis. Intensive Care Med. 2017:43(1):16-28.

7. Egi M, Bellomo R, Stachowski E, French CJ, Hart GK, Hegarty C, et al. Blood glucose concentration and outcome of critical illness: the impact of diabetes. Crit Care Med. 2008;36(8):2249-55.

8. Rady MY, Johnson DJ, Patel BM, Larson JS, Helmers RA. Influence of individual characteristics on outcome of glycemic control in intensive care unit patients with or without diabetes mellitus. Mayo Clin Proc. 2005;80(12):1558-67.

9. Krinsley JS. Glycemic control, diabetic status, and mortality in a heterogeneous population of critically ill patients before and during the era of intensive glycemic management: six and one-half years experience at a university-affiliated community hospital. Semin Thorac Cardiovasc Surg. 2006;18(4):317-25.

10. Whitcomb BW, Pradhan EK, Pittas AG, Roghmann MC, Perencevich EN. Impact of admission hyperglycemia on hospital mortality in various intensive care unit populations. Crit Care Med. 2005:33(12):2772-7.

11. Falciglia M, Freyberg RW, Almenoff PL, D'Alessio DA, Render ML. Hyperglycemia-related mortality in critically ill patients varies with admission diagnosis. Crit Care Med. 2009;37(12):3001-9.

12. Umpierrez GE, Isaacs SD, Bazargan N, You X, Thaler LM, Kitabchi AE. Hyperglycemia: an independent marker of in-hospital mortality in patients with undiagnosed diabetes. J Clin Endocrinol Metab. 2002;87(3):978-82.

13. Egi M, Bellomo R, Stachowski E, French CJ, Hart GK, Taori G, et al. The interaction of chronic and acute glycemia with mortality in critically ill patients with diabetes. Crit Care Med. 2011;39(1):105-11.

14. Plummer MP, Bellomo R, Cousins CE, Annink CE, Sundararajan K, Reddi BA, et al. Dysglycaemia in the critically ill and the interaction of chronic and acute glycaemia with mortality. Intensive Care Med. 2014;40(7):973-80.
15. Egi M, Krinsley JS, Maurer P, Amin DN, Kanazawa T, Ghandi S, et al. Premorbid glycemic control modifies the interaction between acute hypoglycemia and mortality. Intensive Care Med. 2016;42(4):562-71.

16. Di Muzio F, Presello B, Glassford NJ, Tsuji IY, Eastwood GM, Deane AM, et al. Liberal versus conventional glucose targets in critically ill diabetic patients: an exploratory safety cohort assessment. Crit Care Med. 2016:44(9):1683-91.

17. Kar P, Plummer MP, Bellomo R, Jenkins AJ, Januszewski AS, Chapman MJ, et al. Liberal glycemic control in critically ill patients with type 2 diabetes: an exploratory study. Crit Care Med. 2016;44(9):1695-703.

18. Marik PE. Precision glycemic control in the ICU. Crit Care Med. 2016;44(7): 1433-4.

19. Krinsley JS, Preiser JC, Hirsch IB. Safety and efficacy of personalized glycemic control in critically ill patients: a 2-year before and after interventional trial. Endocr Pract. 2017;23(3):318-30.

20. Luethi N, Cioccari L, Biesenbach $P$, Lucchetta L, Kagaya H, Morgan R, et al. Liberal glucose control in ICU patients with diabetes: a before-and-after study. Crit Care Med. 2018;46(6):935-42.

21. Rayfield EJ, Ault MJ, Keusch GT, Brothers MJ, Nechemias C, Smith H. Infection and diabetes: the case for glucose control. Am J Med. 1982;72(3):439-50.

22. Berrios-Torres SI, Umscheid CA, Bratzler DW, Leas B, Stone EC, Kelz RR, et al. Centers for disease control and prevention guideline for the prevention of surgical site infection, 2017. JAMA Surg. 2017:152(8):784-91.

23. Ruhnau B, Faber OK, Borch-Johnsen K, Thorsteinsson B. Renal threshold for glucose in non-insulin-dependent diabetic patients. Diabetes Res Clin Pract. 1997;36(1):27-33.

24. Pittenger GL, Malik RA, Burcus N, Boulton AJ, Vinik Al. Specific fiber deficits in sensorimotor diabetic polyneuropathy correspond to cytotoxicity against neuroblastoma cells of sera from patients with diabetes. Diabetes Care. 1999;22(11):1839-44

25. Van den Berghe G, Wilmer A, Milants I, Wouters PJ, Bouckaert B, Bruyninckx $F$, et al. Intensive insulin therapy in mixed medical/surgical intensive care units: benefit versus harm. Diabetes. 2006;55(11):3151-9.

26. Malmberg K, Ryden L, Efendic S, Herlitz J, Nicol P, Waldenstrom A, et al. Randomized trial of insulin-glucose infusion followed by subcutaneous insulin treatment in diabetic patients with acute myocardial infarction (DIGAMI study): effects on mortality at 1 year. J Am Coll Cardiol. 1995;26(1):57-65.

Ready to submit your research? Choose BMC and benefit from

- fast, convenient online submission

- thorough peer review by experienced researchers in your field

- rapid publication on acceptance

- support for research data, including large and complex data types

- gold Open Access which fosters wider collaboration and increased citations

- maximum visibility for your research: over $100 \mathrm{M}$ website views per year

At BMC, research is always in progress.

Learn more biomedcentral.com/submissions 